\title{
The Role of Bank Credits in Investment Financing of the Small and Medium-sized Enterprise Sector in Poland
}

\section{Introduction}

Small and medium-sized enterprises have considerable impact on economic development. They produce more than 55\% of GNP and employ about $60 \%$ of all human resources, including $39.5 \%$ employed by micro enterprises, $15.2 \%$ by small, and $24.4 \%$ by medium-sized enterprises [21]. However, these entities encounter a range of barriers to their development, in particular of a financial nature. Specialists believe growth of such enterprises is largely dependent on access to external sources of financing. Efficient obtaining and utilisation of capital may strengthen competitive standing of a company, help survive in the market and undertake pro-development projects. Investment into innovation, which requires significant capital commitment, is a factor in building a lasting competitive advantage. Polish SMEs have long financed their investments from three sources: own capital (insufficient for such expenditure) bank credits and leasing. Problems are commonly mentioned that these enterprises have obtaining bank credits. Therefore, this paper analyses sources of financing for investment activities of the Polish sector, particularly focusing on the role of bank crediting in this process. This objective is realised through a review of relevant literature and analysis of empirical results published by the Polish Confederation of Private Employers 'Lewiatan', Polish Agency for Enterprise Development (PARP), the Economy Ministry, National Office for Statistics (GUS), and the author's own research.

\footnotetext{
* AGH University of Science and Technology, Faculty of Management
} 


\section{Bank credits as a source of investment financing of Polish small and medium-sized enterprises}

Funds for day-to-day activities, that is, current account overdraft, current account credit or revolving credit, are easiest to obtain among crediting products. Long-term (investment) crediting, awarded only to small and medium-sized enterprises of impeccable financial credentials, is the most inaccessible source of financing, on the other hand. In this case, banks require excellent collateral from entrepreneurs. In respect of bank product pricing, commissions and margins charged to smaller businesses continue to remain higher than those available to larger corporations or even individuals [20]. Such practices may be a sign of discrimination against small and medium-sized enterprises in the banking market [5]

A client can additionally be charged with a range of such other costs as:

- other commissions (for consideration of an application, initial fee, currency conversion fee, for earlier/ later repayment, credit handling, for unused funding)

- valuation fees, e.g. concerning collateral,

- fees for contract variations,

- fees for the evaluation of investment progress,

- currency spread (in the case of currency crediting),

- credit insurance.

Schedule of credit repayment is rarely listed among factors affecting prices. A debtor may elect to repay a credit over decreasing instalments (identical capital instalments in the entire credit term) or in equal portions. Specialist opinion is divided as to advantages of either option to debtors. [7]

The issue of the choice of a repayment schedule is usually presented in three ways:

If a debtor has sufficient capital to support the diminishing repayments, the cost of crediting will be lower than that of equal instalments [6]

Cost of crediting repaid in equal instalments is the same as the cost of crediting repaid over declining instalments [8]

When the advantages of crediting are considered with regard to a schedule of repayments, the possibility of reinvesting funds from the time when instalments paid in the schedule of identical payments are lower than as part of the diminishing instalments schedule must be taken into account.

Bank credits are the most common third-party source of financing for SME investments. Their chief advantages comprise such factors as: retention of business ownership, spread of repayments over time, interest reducing base of taxation. 
The Role of Bank Credits in Investment Financing...

This form has its drawbacks, too, including the relatively high cost of crediting and compulsory restrictions implied by credit agreements [4]

A.N. Berger et al. are of the opinion that large banks are reluctant to finance activities of small businesses due to the limited scale of the latter's operations and excessive costs of acquiring knowledge of their local markets [1]

Smaller banks, active in local markets, are much more willing to credit SMEs, on the other hand. This is due to small scale of crediting for individual small enterprises, more detailed assessment of financial standing of individual debtors and its further monitoring[19].

\section{Accessibility of financing sources for the Polish SME sector in 1999-2012}

As Polish SMEs face problems obtaining third-party capitals, their own resources, i.e. retained profits and owner contributions, have been the principal source of funding. Bank crediting is the second most frequent source of financing. Many more entrepreneurs had taken advantage of this source in 1999-2000, yet banks commenced to apply increasingly stricter criteria of crediting, chiefly due to numbers of lost credits and high proportion of businesses operating for less than a year. Interest in leasing has also been declining. The structure of financing investment by the Polish SME sector in 1999-2011 is illustrated in Table 1.

Table 1

Sources of financing for the Polish SME sector in 1999-2011

\begin{tabular}{|l|c|c|c|c|c|c|c|c|c|}
\hline \multirow{2}{*}{ Specification } & \multicolumn{7}{|c|}{ The percentage of companies [in\%] } \\
\cline { 2 - 11 } & 2000 & $\mathbf{2 0 0 4}$ & $\mathbf{2 0 0 5}$ & $\mathbf{2 0 0 6}$ & $\mathbf{2 0 0 7}$ & $\mathbf{2 0 0 8}$ & $\mathbf{2 0 0 9}$ & $\mathbf{2 0 1 0}$ & $\mathbf{2 0 1 1}$ \\
\hline $\begin{array}{l}\text { Shareholders' } \\
\text { equity including } \\
\text { retained earnings }\end{array}$ & 76 & 86 & 69.1 & 73.1 & 72.6 & 74.1 & 64.8 & 64 & 65 \\
\hline Bank credit & 38 & 14.2 & 16.6 & 12.7 & 17.4 & 12.8 & 17.7 & 10 & 12 \\
\hline Leasing & 24 & 12.6 & 10.5 & 9.0 & 6.9 & - & 8.3 & 8 & 11 \\
\hline EU Funds & 0 & 3.6 & 1.4 & 1.9 & 1.9 & 6.5 & 7.3 & - & 2 \\
\hline Other & 0 & 0 & 2.4 & 3.3 & 1.2 & 2.9 & 1.9 & - & - \\
\hline
\end{tabular}

Source: author's own compilation based on: $[7,14]$ 
The figures in Table 1 point to declining numbers of entrepreneurs using bank credits or leasing in the eleven years under analysis. Nearly $40 \%$ of enterprises took advantage of crediting in 1999-2000, compared to merely 12\% in 2011.

Obtaining of investment credits by the small and medium-sized enterprise sector is highly difficult, banks are much more prone to offering short-term investment crediting, associated with the lower risk of non-repayment. Only $6 \%$ of the businesses awarded bank crediting in 2011 obtained investment credits. Most entrepreneurs received current account or day-to-day business credits.

The figures in Table 2 suggest every third entrepreneur surveyed (29\% of microenterprises, a half of the small businesses, and more than two thirds of medium-sized enterprises) took crediting in 2008. The share of business credit applicants grew in the second half of 2008 (from 20 to 26\%). Since banks were applying more stringent criteria of credit awards, more than half of the businesses were rejected (compared to just $20 \%$ of entrepreneurs in the first half of 2008). Micro-entrepreneurs found it hardest - only $41 \%$ of the companies surveyed were accepted by banks. The starting year of a company affected bank decisions as well. Two-thirds of those founded between 2000 and 2004 and approximately a half of those established before 2000 were awarded their credits. The youngest businesses found it the most difficult to obtain crediting: only $38 \%$ of those started after 2004 received crediting.

The structure of business crediting shifted in 2009. Revolving and current account crediting became more popular, with fewer respondents pointing to investment crediting (this was particularly striking among medium-sized enterprises). This is related to the shrinking liquidity of businesses and limited investment operations. The share of business credit applicants grew by 3\% (from 26\% in 2008 to 29\%). $42 \%$ applicants were awarded crediting in 2009 , that is, $8 \%$ fewer than a year before.

In the second half of $2010,30 \%$ of entrepreneurs asked stated they were taking advantage of crediting in their businesses (the proportion had remained steady since 2009). 28\% of companies applied for investment bank crediting. Every second business was awarded the credit it applied for (26\% micro-enterprises, as many as $50 \%$ small companies, and $62 \%$ of medium-sized enterprises). Credits were most often refused on the grounds of poor rating (half the cases). Every fifth business cited absence of collateral, the others incomplete documentation or other reasons.

Companies most frequently resorted to current account crediting (22\%) in 2011. Nearly a tenth took advantage of revolving credit, and $6 \%$ of investment credits. More businesses applied for investment or revolving credit: $30 \%$ of those surveyed did so in the first half of 2011. Every second obtained the crediting it had sought (25\% of micro-enterprises and 50\% of small and medium-sized enterprises).

Like a year before, every third business took advantage of crediting in 2012 (29\% of micro-enterprises, 63 small and 69\% medium-sized enterprises).

Companies normally utilised current account crediting (23\%), 8\% entrepreneurs used revolving and $6 \%$ investment crediting. 
The Role of Bank Credits in Investment Financing...

In the first half of 2012 , barely $12 \%$ of the businesses asked applied for investment or revolving credits - considerably fewer than in the preceding years, when the share reached approximately $30 \%$. Every tenth micro and medium-sized company and every fourth of small businesses applied for crediting.

Table 2

Proportion of enterprises credited in 2008-2012

\begin{tabular}{|c|c|c|c|c|c|c|}
\hline \multirow[t]{2}{*}{$\begin{array}{l}\text { Type of } \\
\text { credit }\end{array}$} & \multirow{2}{*}{ Year } & $\begin{array}{c}\text { Bank over- } \\
\text { draft }\end{array}$ & $\begin{array}{c}\text { Working } \\
\text { capital } \\
\text { credit }\end{array}$ & $\begin{array}{c}\text { Invest- } \\
\text { ment } \\
\text { credit }\end{array}$ & $\begin{array}{l}\text { Other type } \\
\text { of credit }\end{array}$ & Total \\
\hline & & \multicolumn{5}{|c|}{ The percentage of enterprises [in\%] } \\
\hline \multirow[t]{5}{*}{ Micro } & 2008 & 15 & 5 & 6 & 4 & 30 \\
\hline & 2009 & 14 & 4 & 5 & 3 & 26 \\
\hline & 2010 & 12 & 5 & 4 & 2 & 26 \\
\hline & 2011 & 17 & 6 & 3 & 2 & 25 \\
\hline & 2012 & 20 & 4 & 3 & 5 & 29 \\
\hline \multirow[t]{5}{*}{ Small } & 2008 & 38 & 13 & 16 & 1 & 50 \\
\hline & 2009 & 38 & 22 & 15 & 7 & 52 \\
\hline & 2010 & 32 & 22 & 14 & 2 & 50 \\
\hline & 2011 & 33 & 16 & 17 & 13 & 50 \\
\hline & 2012 & 36 & 23 & 18 & 5 & 63 \\
\hline \multirow[t]{5}{*}{ Medium } & 2008 & 36 & 20 & 24 & 7 & 66 \\
\hline & 2009 & 45 & 18 & 5 & 5 & 67 \\
\hline & 2010 & 46 & 8 & 23 & 3 & 62 \\
\hline & 2011 & 39 & 17 & 20 & 2 & 50 \\
\hline & 2012 & 43 & 26 & 26 & 11 & 69 \\
\hline
\end{tabular}

Source: author's own compilation based on: $[14,15,16,17,18]$

Every second business credit applicant was awarded the crediting it sought. The most, that is, as many as $78 \%$ medium-sized enterprises were successful applicants, compared with $62 \%$ of small companies and $35 \%$ of micro-enterprises.

Surveys were conducted among the three most popular Banking Capital Groups operating in Poland in order to assess the potential for obtaining bank credits by small and medium-sized enterprises in June 2012. The research, summarised in Table 3, suggests the banks offer both investment and revolving credits. In addition, two of those groups offer a broad range of factoring, leasing and other services. 
Table 3

Banking products offered to SME sector

\begin{tabular}{|l|c|c|c|}
\hline \multicolumn{1}{|c|}{ Type of service } & BZ WBK SA & Bank Spółdzielczy & PKO BP SA \\
\hline Working capital credit & $\mathrm{x}$ & $\mathrm{x}$ & $\mathbf{x}$ \\
\hline Investment credit & $\mathrm{x}$ & $\mathrm{x}$ & $\mathbf{x}$ \\
\hline Loan & $\mathrm{x}$ & - & $\mathbf{x}$ \\
\hline Factoring & $\mathrm{x}$ & - & $\mathbf{x}$ \\
\hline Leasing & $\mathrm{x}$ & - & $\mathbf{x}$ \\
\hline Deposit & $\mathrm{x}$ & $\mathrm{x}$ & $\mathbf{x}$ \\
\hline $\begin{array}{l}\text { Bank account mainte- } \\
\text { nance }\end{array}$ & - & - & $\mathbf{x}$ \\
\hline Other & &
\end{tabular}

Source: author's own research

The banks declared offering credits for the SME sector yet, as the figures in Table 4 demonstrate, none provided investment crediting for micro-enterprises, which confirms the earlier proposition that micro-enterprises find bank investment crediting less accessible than small and medium-sized enterprises.

Table 4

Beneficiaries of bank credits

\begin{tabular}{|l|c|c|c|}
\hline \multicolumn{1}{|c|}{ Type of enterprise } & BZ WBK SA & Bank Spółdzielczy & PKO BP SA \\
\hline Micro & - & - & - \\
\hline Small & - & $\mathbf{x}$ & $\mathbf{x}$ \\
\hline Medium & $\mathrm{x}$ & $\mathbf{x}$ & $\mathbf{x}$ \\
\hline
\end{tabular}

Source: author's own research

In their assessment of credit applications, banks primarily take into consideration credit histories, the key problem of the Polish SME sector, particularly of micro-enterprises which have normally operated for short period of time (Table 5). GUS informs approx. 50\% of new SMEs operate for less than a year, with $75 \%$ collapsing in the first three years of business. The amount of collateral is an additional barrier to crediting. 
The Role of Bank Credits in Investment Financing...

Table 5

Elements in assessment of creditworthiness by banks

\begin{tabular}{|l|c|c|c|}
\hline $\begin{array}{c}\text { Elements of credit- } \\
\text { worthiness examination }\end{array}$ & BZ WBK SA & Bank Spółdzielczy & PKO BP SA \\
\hline Credit history & - & $\mathbf{x}$ & $\mathbf{x}$ \\
\hline Possible collaterals & $\mathbf{x}$ & $\mathbf{x}$ & $\mathbf{x}$ \\
\hline $\begin{array}{l}\text { Economic and financial } \\
\text { situation }\end{array}$ & - & entrepreneur's & assets \\
\hline Other & & $\begin{array}{c}\text { assessment of } \\
\text { qualitative and } \\
\text { quantitative indi- } \\
\text { cators }\end{array}$ \\
\hline
\end{tabular}

Source: author's own research

Due to the low credit rating of the Polish SME sector, banks require collaterals of between $120 \%$ and $150 \%$ of credit value. In the opinion of banks included in Table 6 , promissory notes, mortgage and pledge of chattels are credit collaterals of choice.

Table 6

Means of collateral preferred by banks

\begin{tabular}{|c|c|c|c|}
\hline Means of collateral & BZ WBK SA & Bank Spółdzielczy & PKO BP SA \\
\hline Promissory note & $\mathbf{x}$ & $\mathrm{X}$ & $\mathbf{x}$ \\
\hline Mortgage & $\mathbf{x}$ & $\mathrm{X}$ & $\mathbf{x}$ \\
\hline Guarantee & - & - & $\mathbf{x}$ \\
\hline Alienation & & $\mathbf{x}$ & - \\
\hline Pledge of chattels & $\mathbf{x}$ & $\mathbf{x}$ & $\mathbf{x}$ \\
\hline $\begin{array}{l}\text { Power of attorney to } \\
\text { the account }\end{array}$ & - & - & $\mathbf{x}$ \\
\hline $\begin{array}{l}\text { Blocking of funds in } \\
\text { bank accounts }\end{array}$ & - & - & $\mathbf{x}$ \\
\hline
\end{tabular}

Source: author's own research 


\subsection{Bank credit interest in 2008-2012}

High costs of bank crediting are among the most important barriers encountered by small and medium-sized enterprises. In 2012, credit interest averaged $9 \%$ and remained virtually unchanged since the second half of 2011 . Mediumsized enterprises pay lowest and micro-enterprises higher interest on their credits (Table 7).

Table 7

Average credit interest for the SME sector in 2008-2012

\begin{tabular}{|l|c|c|c|c|c|c|}
\hline \multirow{2}{*}{ Years } & \multicolumn{6}{|c|}{ Percentage of enterpreneurs [\%] } \\
\cline { 2 - 7 } & Micro & Small & Medium & $\begin{array}{c}\text { Difference } \\
\text { Micro- } \\
\text { Small }\end{array}$ & $\begin{array}{c}\text { Difference } \\
\text { Micro- } \\
\text { Medium }\end{array}$ & $\begin{array}{c}\text { Difference } \\
\text { Small- } \\
\text { Medium }\end{array}$ \\
\hline 2008 & 10.5 & 10 & 8.5 & 0.5 & 2.0 & 1.5 \\
\hline 2009 & 12 & 8.5 & 7.0 & 3.5 & 4.0 & 1.5 \\
\hline 2010 & 10 & 8.0 & 6.5 & 2.0 & 3.5 & 1.5 \\
\hline 2011 & 11 & 7.0 & 8.0 & 4.0 & 3.0 & 1.0 \\
\hline 2012 & 10 & 7.0 & 8.0 & 3.0 & 3.0 & 2.0 \\
\hline
\end{tabular}

Source: author's own compilation based on: $[14,15,16,17,18]$

The figures in Table 7 show bank crediting offered to micro-enterprises was more expensive (by $0.5 \%$ in 2008 and as much as $4 \%$ in 2012) than that offered to small businesses. The differences are even greater of interest provided to micro and medium-sized enterprises.

This analysis reaffirms that micro-enterprises, $70 \%$ of all Polish SME enterprises, are normally offered worse terms of crediting than the other groups in the sector. Difficulties with bank crediting translate into implementation of investment, especially those associated with innovation, as they exhibit higher capital requirements. The structure of investment by Polish SMEs will be discussed below.

\subsection{Structure of investment by the Polish SME sector}

Half the entrepreneurs did not undertake any investments in 2003-2011. Investment in computers and IT systems prevailed among enterprises investing before Poland's accession to the EU (more than 60\% small and medium-sized enterprises). These decisions seem reasonable as more than $50 \%$ enterprises at the time did not have computer systems or Internet access. Entrepreneurs also 
The Role of Bank Credits in Investment Financing...

bought production plant and machinery, both new and second-hand. Investments into machinery of production parameters similar to those of the equipment already held, in the development of sales networks, improvement of services, purchase of state-of-the-art manufacturing plant and machinery were also noted in 2004 . These investments were chiefly motivated by the desire to meet heavy competition in the EU market [2].

The structure of investments changed markedly after 2005. Most businesses began investing in new production plant and machinery with a view to launching of new products and services. The percentage of enterprises interested in innovative investment has declined a little since 2007 , as demonstrated by lower numbers of investors into machinery and equipment owing to their new technology (Table 8). The low demand for innovative products in the Polish market might be another reason for this abandonment of innovative and thus costly investment. This is caused by the fact that a majority of Polish consumers are price-oriented when making their purchase decisions.

Table 8

Structure of investment by the Polish SME sector in 2003-2010

\begin{tabular}{|l|c|c|c|c|c|c|c|}
\hline \multirow{2}{*}{\multicolumn{1}{|c|}{ Type of investment }} & \multicolumn{7}{c|}{ Percentage of enterprises [\%] } \\
\cline { 2 - 8 } & 2003 & 2004 & 2005 & 2006 & $\begin{array}{c}2007- \\
\text { 2008 }\end{array}$ & 2009 & 2010 \\
\hline $\begin{array}{l}\text { Purchase of machines and } \\
\text { devices in regard of a new } \\
\text { technology }\end{array}$ & - & - & 32.0 & 29.3 & 21.9 & 21.5 & 21.5 \\
\hline $\begin{array}{l}\text { Purchase of machines and } \\
\text { devices of similar production } \\
\text { parameters }\end{array}$ & 42 & 44 & 28.1 & 34.3 & 17.9 & 18.6 & 18.6 \\
\hline Used machines and devices & 23.5 & - & - & - & - & - & - \\
\hline $\begin{array}{l}\text { Construction or purchase of } \\
\text { buildings }\end{array}$ & & & 22.4 & 18.4 & 14.9 & 10.8 & 10.8 \\
\hline $\begin{array}{l}\text { Replacement of machines and } \\
\text { devices with similar ones }\end{array}$ & - & - & 27.9 & 20.1 & 10.0 & 9.0 & 9.0 \\
\hline $\begin{array}{l}\text { Modernisation of transport } \\
\text { means }\end{array}$ & 41.5 & 8.1 & 27.9 & 23.6 & 8.4 & 6.6 & 6.6 \\
\hline Quality improvement & - & 13.9 & 25.9 & 30.6 & 7.4 & 7.4 & 7.4 \\
\hline Introdution of new products & - & - & 30.1 & 24.3 & 5.1 & 4.4 & 4.4 \\
\hline Diversification of activities & - & - & - & - & 3.8 & 1.9 & 1.9 \\
\hline
\end{tabular}

Source: author's own compilation based on: [7, 10, 13] 
Investments are one of the key ways of realising business growth. The need for investments is motivated by escalating competition in the market, changing environment and growing customer expectations. At a time of rapid technical progress and market competition, features such as innovation, modernising spirit and flexibility provide opportunities for survival and development. These characteristics are implemented via investment which assures continuing operation and effective competition [19].

\section{Accessibility of financing for Lesser Poland SME sector in 2010-2012}

Results of the author's research into a sample of 100 Lesser Poland microenterprises in 2009-2011 will be presented in this section.

Retained profits and owner capital constituted principal sources of financing for Lesser Poland micro-enterprises, like in the entire Polish SME sector. In addition, 6\% respondents obtained venture capital only in 2009 (Table 9).

Table 9

Sources of investment financing in Lesser Poland micro-enterprises in 2009-2011

\begin{tabular}{|l|c|c|c|}
\hline \multirow{2}{*}{ Sources of financing } & \multicolumn{3}{|c|}{ The percentage of micro enterprises using equity capital [\%] } \\
\cline { 2 - 4 } & $\mathbf{2 0 0 9}$ & $\mathbf{2 0 1 0}$ & $\mathbf{2 0 1 1}$ \\
\hline Profit & 52 & 71 & 73 \\
\hline Owner's capital & 42 & 75 & 53 \\
\hline Venture capital & 6 & 0 & 0 \\
\hline Bank credit & 32 & 14 & 33 \\
\hline Leasing & 29 & 14 & 20 \\
\hline Factoring & 0 & 0 & 0 \\
\hline Franchising & 0 & 0 & 0 \\
\hline Guarantee & 3 & 0 & 0 \\
\hline Loan funds & 3 & 0 & 0 \\
\hline Business incubator & 3 & 0 & 0 \\
\hline Other & 0 & 0 & 0 \\
\hline
\end{tabular}

Source: author's own research 
The Role of Bank Credits in Investment Financing...

The figures in Table 9 indicate that bank crediting was only employed by a few entrepreneurs, which is also the case for the Polish SME sector as a whole. Only a few obtained pledges from credit pledge funds, aid from enterprise think-tanks was utilised to a limited extent as well. Only banking credits and leasing were taken advantage of among third-party capitals.

Significantly (18\%) fewer businesses used bank crediting and 15\% fewer financed their investments with leasing in 2010 when compared to 2009 . None employed venture capital funding, aid from credit pledge funds or enterprise think-tanks. The share of entrepreneurs using bank credits rose again to 33\% and those taking advantage of leasing to $20 \%$ in 2011 , on the other hand.

Due to problems with obtaining bank credits, some entrepreneurs financed their planned investments with private bank crediting which was then allocated to investments. The research results are illustrated in Table 10.

Table 10

Share of entrepreneurs realising their investments with private bank crediting in 20092011

\begin{tabular}{|l|c|c|c|}
\hline \multirow{2}{*}{$\begin{array}{c}\text { The use of bank loans } \\
\text { to individuals }\end{array}$} & \multicolumn{3}{|c|}{ The percentage of enterprises using loans to individuals [\%] } \\
\cline { 2 - 4 } & $\mathbf{2 0 0 9}$ & $\mathbf{2 0 1 0}$ & $\mathbf{2 0 1 1}$ \\
\hline Use & 6 & 4 & 13 \\
\hline Do not use & 69 & 86 & 60 \\
\hline Intend to use & 25 & 11 & 27 \\
\hline
\end{tabular}

Source: author's own research

The figures in Table 10 suggest that $2 \%$ fewer businesses took advantage of this form of crediting in 2010 and 14\% fewer intended to obtain such resources. In 2011, the proportion of SME entrepreneurs financing investments with private bank credits rose sharply (to reach $13 \%$ ), which might be a result of a lower consumption of investment crediting.

In 2009-2011, the Lesser Poland microentrepreneurs surveyed invested mainly in: machinery of production parameters similar to those of the equipment already held, machinery and equipment owing to their new technology, improvement of quality, purchase licences and patents. One should note most of these investments were innovative in nature. The results are shown in Table 11.

Some differences in the structure of investments can be noted in that period. In 2009, considerably more companies (16\% more than in 2010 and $21 \%$ more than in 2011) invested in machinery of parameters similar to those already held. The numbers of enterprises investing in equipment owing to its new technology, 
licences and patents were steady in 2009-2010, yet dropped by $12 \%$ in 2011 . The number of enterprises investing in technologies and environment protection suffered a similar decline, perhaps due to the credit crunch and the consequent low demand for investment in the Polish market. Markedly more companies invested in the refurbishment of their offices, meanwhile.

\section{Table 11}

Structure of investments by Lesser Poland micro-enterprises in 2009-2011

\begin{tabular}{|c|c|c|c|}
\hline \multirow[t]{2}{*}{ Investments structure } & \multicolumn{3}{|c|}{$\begin{array}{c}\text { Percentage of micro enterprises realizing } \\
\text { investments [\%] }\end{array}$} \\
\hline & 2009 & 2010 & 2011 \\
\hline Machines and devices for production & 34 & 18 & 13 \\
\hline Machines/new technologies & 32 & 32 & 20 \\
\hline Licenses and patents & 21 & 21 & 13 \\
\hline New technologies & 21 & 43 & 13 \\
\hline Environmental protection & 3 & 7 & 0 \\
\hline $\mathrm{R} \& \mathrm{D}$ & 5 & 14 & 0 \\
\hline Quality improvement & 37 & 46 & 47 \\
\hline Implementing a quality system & - & 7 & 0 \\
\hline Informatisation & 24 & 43 & 0 \\
\hline Office modernisation & 5 & 18 & 27 \\
\hline Trainings & 5 & - & 0 \\
\hline Transport & - & 4 & 0 \\
\hline Other & - & 4 & 7 \\
\hline
\end{tabular}

Source: author's own research

\section{Conclusion}

Results of the research discussed in this paper demonstrate Polish SMEs have faced and are still facing difficulties obtaining third-party capital. Own capital, most frequently retained profits, constituted the principal source of financing in 2000-2011, since civil partnerships and self-employed individuals, where owner capital is normally low and insufficient for investments, are the prevailing legal forms among Polish SMEs. 
The Role of Bank Credits in Investment Financing...

Numbers of enterprises taking advantage of bank credits markedly varied in the eleven years under analysis (Table 1). Nearly a quarter of entrepreneurs took bank crediting in the late 1990 s and in 2000 yet, due to high rates of unpaid credits, banks applied palpably more stringent crediting policies, which has sharply reduced the number of entities utilising this source.

An analysis of available data suggests banks are more willing to award revolving and current account credits to SME entrepreneurs. The regularity can also be observed that the smaller a business, the poorer terms of credit it is offered (Table 2). It appears that most commercial banks do not supply crediting to micro-enterprises. In the face of the high risk posed by this group, banks require three years of credit histories and collateral to $120 \%-150 \%$ of the credit value.

High costs of obtaining bank credits are another barrier to small and mediumsized enterprises. The figures in Table 7 suggest that credits offered to microenterprises bear higher interest than those available to small and medium-sized enterprises. Some micro-entrepreneurs attempt to bridge this capital gap with crediting for private individuals (Table 10).

The restricted access to long-term bank crediting directly translates into the structure of investments and the degree of their innovative nature. In 2003-2011, more than a half of SME entrepreneurs failed to undertake any investment projects. Merely $20 \%$ of those who did invested in broadly-defined innovation, a principal factor underpinning the long-term competitive advantage of market enterprises.

\section{References}

[1] Berger A.N., Klapper L.F., Udell G.F., The ability of banks to lend informationally opaque small businesses, "Journal of Banking \& Finance", Issue 25, 2001.

[2] Duda J., Decyzje inwestycyjne przedsiębiorstw polskich z sektora MSP, in: Prace Naukowe Uniwersytetu Ekonomicznego, Wydawnictwo Uniwersytetu Ekonomicznego, Wrocław, 2009.

[3] Duda J., Strategie finansowania działalności inwestycyjnej polskich MSP na rynku Unii Europejskiej, Zeszyty Naukowe Uniwersytetu Szczecińskiego 685, Finanse, Rynki Finansowe, Ubezpieczenie nr 46, Szczecin 2011,

[4] Flejterski S., Specyfika i źródta finansowania mikro- i matych przedsiębiorstw, in: Zarzadzanie finansami. Zarządzanie i kreowanie wartości, ed. D. Zarzecki, Wydawnictwo Naukowe Uniwersytetu Szczecińskiego, Szczecin 2007.

[5] Łuczka T., Kapital obcy w malym i średnim przedsiębiorstwie, Wydawnictwo Naukowe PWN, Warszawa-Poznań 2001.

[6] Michalczewski A., Kredyty inwestycyjne. Sposoby zabezpieczania przed ryzykiem stopy procentowej i ryzykiem walutowym, in: Finansowanie rozwoju przedsiębiorstwa - studia przypadku, red. M. Panfil, Difin, Warszawa 2008. 
[7] Monitoring kondycji sektora MSP, PKPP Lewiatan, Warszawa 2004, 2005, 2006, 2007, 2009, 2010, 2011, 2012.

[8] Przepióra P., Koszt kredytu $w$ matych i średnich firmach a harmonogram jego splaty, Zeszyty Naukowe Uniwersytetu Szczecińskiego, Ekonomiczne problemy usług nr 51, Szczecin 2010.

[9] Raport o stanie sektora matych $i$ średnich przedsiębiorstw $w$ Polsce $w$ latach 2006-2007, ed. A. Żołnierski, P. Zadura-Lichota, Polska Agencja Rozwoju Przedsiębiorczości, Warszawa 2008.

[10] Raty równe i raty malejące kredytu hipotecznego - jakie wybrać?, protokół dostępu: http:// www.finansegoc.pl/poradnik.php?art=2 [04.12.2009] lub Raty malejace czy state?, protokół dostępu: http://www.muratordom.pl/ prawo-i-pieniadze/kredyty-i-pozyczki/raty-malejace-czy-stale_,7269_3916.htm [04.12.2009].

[11] Rutkowski A., Zarządzanie finansami, PWE, Warszawa 2003.

[12] Starczewska-Krzysztoszek M., Bariery rozwoju matych $i$ średnich przedsiębiorstw w Polsce, in: ,infos”, Biuro Analiz Sejmowych, nr 4, 2008.

[13] Trendy rozwojowe sektora MSP $w$ ocenie przedsiębiorców w pierwszej potowie 2012 roku, MG DPiA, nr 2/2012, Warszawa 2012.

[14] Trendy rozwojowe sektora MSP $w$ ocenie przedsiębiorców w pierwszej potowie 2011 roku, MG DPiA, nr 2/2011, Warszawa 2011.

[15] Trendy rozwojowe sektora MSP $w$ ocenie przedsiębiorców $w$ pierwszej potowie 2010 roku, MG DPiA, nr 2/2010, Warszawa 2010.

[16] Trendy rozwojowe sektora MSP $w$ ocenie przedsiębiorców w pierwszej potowie 2009 roku, MG DPiA, nr 2/2009, Warszawa 2009.

[17] Trendy rozwojowe sektora MSP $w$ ocenie przedsiębiorców w pierwszej potowie 2008 roku, MG DPiA, nr 2/2008, Warszawa 2008.

[18] Vos E., Jia-Yuh Yeh A., Carter S., Tagg S., The happy story of small business financing, "Journal of Banking \& Finance" Issue 31, 2007.

[19] Wolak-Tuzimek A., Dziatalność inwestycyjna polskich przedsiębiorstw, in: Zeszyty Naukowe Uniwersytetu Szczecińskiego 639, Zarządzanie Finansami, Inwestycje, Wycena Przedsiębiorstw, Zarządzanie Wartością, Szczecin 2011.

[20] Wolański R., Relacje między bankami a malymi i średnimi przedsiębiorstwa$m i$, w: Prace Naukowe Katedry Ekonomii i Zarządzania Przedsiębiorstwem, ed. F. Bławat, t. IV, Gdańsk 2005. 